УДК 378:373.3.091.12.011.3-051]:004(410) (043.5)

DOI: $10.24144 / 2524-0609.2020 .47 .43-46$

\author{
Harapko Vitaliia \\ Candidate of Pedagogical Sciences, Ph.D., Associate Professor \\ Department of English Philology and Methods of Teaching English Language and Foreign Literature \\ Mukachevo State University \\ Mukachevo, Ukraine \\ v.garapko@gmail.com \\ ORCID ID: http://orcid.org/0000-0001-7171-8448
}

\title{
DEVELOPING ENGLISH LANGUAGE COMPETENCE IN AN ACADEMIC ENVIRONMENT FOR PhD-STUDENTS
}

\begin{abstract}
The high level of personal involvement required by the foreign language learning process is even more difficult for our universities, where the demands of the academic environment are so high that not all graduate students acquire the necessary competencies to meet these requirements. The purpose of the article is to explore the background for acquiring foreign language competence in the academic environment. The research methodology is based mainly on theoretical methods, such as analysis of scientific papers and publications to identify the main problems of the article. The classification method is used to classify the main points of view on the selected problem. The broader goal of language education is independent communication in a foreign language, which is based on the premise that language skills learned in classrooms are easy to transfer to real situations, and that graduate students will gain the necessary experience at the end of the language program. But this is not the case, and the practical results of the acquired skills of communication in a foreign language almost always do not meet the language expectations of the applicants. The current state of educational services indicates a significant increase in the need for high-quality post-graduate education, providing applicants with relevant competencies relevant to the academic environment. In light of this, teachers and $\mathrm{PhD}$ students should spend much more time talking about why and how they teach and learn languages. It would also expand the scope of teaching beyond, as a rule, results-oriented, utilitarian orientation. This means paying attention to the teaching process and foreign language competence. More attention should be paid to subjectivity and $\mathrm{PhD}$ student experience, an important component of language acquisition. Post-graduate education established the imperative of the competence-based approach, while communicative competencies aren't directed to the process of inclusion of $\mathrm{PhD}$ students in professional culture and remain underestimated.
\end{abstract}

Key words: communicative competence; competence in foreign languages; PhD students; difficulties in the process of acquiring language competence; academic environment.

Introduction. According to the Resolution of the Cabinet of Ministers of Ukraine of March 23, 2016 №261 «On approval of the Procedure for training applicants for higher education degree of Doctor of Philosophy and Doctor of Science in higher educational institutions (scientific institutions)» entrance examinations for the degree of Doctor of Philosophy consist of exam: in the specialty (in the amount of the standard of higher education master's degree in the relevant specialty); in a foreign language (at the choice of the Academic Council of a higher education institution (scientific institution) in the amount corresponding to level B2 of the European Recommendations on Language Education).

An entrant who has confirmed the level of knowledge, in particular English, with a valid Test of English as a Foreign Language (TOEFL) test, or the International English Language Testing System (IELTS), or a Cambridge English (FCE, CAE, CPE) certificate at the level of below B2, is exempt from taking the entrance exam in a foreign language. In determining the results of the competition, these certificates are equated to the results of the entrance examination in a foreign language with the highest score. Entrants are to submit to the examination commission literature in the relevant foreign language in their specialty in the amount of 300 pages (monographs, journals, collections of articles, materials on the Internet, etc.). These materials are presented directly to the audience where exam is held. Entrance examinations for $\mathrm{PhD}$ students are conducted in accordance with the following requirements: lexical and grammar test (60 minutes); written translation from a foreign language into the native language with the help of a dictionary of text from the specialty of 1500 printed signs in 45 minutes; oral interview in a foreign language related to the entrant's biography, research interests and plans, as well as current socio-political events in Ukraine and abroad [1].
The main form of PhD students training at the third (educational and scientific) level of higher education is a training at higher educational institutions and research institutions, where there are highly qualified scientific and pedagogical and scientific staff, modern research, experimental and material base. During the study $\mathrm{PhD}$ students are obliged to fulfill all the requirements of the educational and scientific programme, in particular to gain in-depth knowledge of the specialty (groups of specialties), for which $\mathrm{PhD}$ students conduct research, master general scientific (philosophical) competencies, to acquire universal skills of a researcher, to acquire language competencies that are necessary to present and discuss the results his scientific work in a foreign language orally and in writing, as well as for a full understanding of foreign scientific texts from the relevant specialties [5]. Thus, the training can not be implemented without due attention to language issues education and training for intercultural communication.

Analysis of scientific literature and study of the experience of foreign language training of $\mathrm{PhD}$ students [2] indicate that there is a need for further development of theoretical and practical aspects of foreign language education, promoting effective mastery of a foreign language as a means of intercultural, professional communication in various fields scientific activity.

The issues of foreign language education of $\mathrm{PhD}$ students are reflected in the works of modern scholars, who have studied: (i) historical, theoretical, methodological and practical issues of foreign language teaching in graduate school of non-language universities - G.Buyanova, A.Kinderkercht, O.Peunova, T.Popova, M.Fedotova, O.Yaroslavova; (ii) features of independent work organization of $\mathrm{PhD}$ students in the process of learning a foreign language - A.Kinderkercht, L.Peleh, N.Shumakova; (iii) teaching academic writing 
- S.Kozhushko, I.Korotkina, T.Popova, O.Tarnopolskyj, L.Yahenich; (iv) theory of language and intercultural communication - V.Krasnych, Yu.Karaulov, V.Teliia; (v) theoretical and methodological bases of application of interactive technologies - L.Artemova, S.Goncharenko, A.Zyazyun, T.Nazarova, O.Pometun.

The aim of the article is to research the background of gaining the foreign language communication competence in an academic environment.

Research methodology. This descriptive research is built mostly on theoretical methods: analysis of sci- entific works and publications for identifying the main tasks of the article; classification method - to classify the main points of view on the issue under consideration.

Research results. There is no general agreement in the Ukrainian higher education system on what competencies for language communicating $\mathrm{PhD}$ students are to acquire. However, there does seem to be some consensus on classifying language communication competencies into linguistic, strategic, socio-linguistic and discourse (Fig. 1).

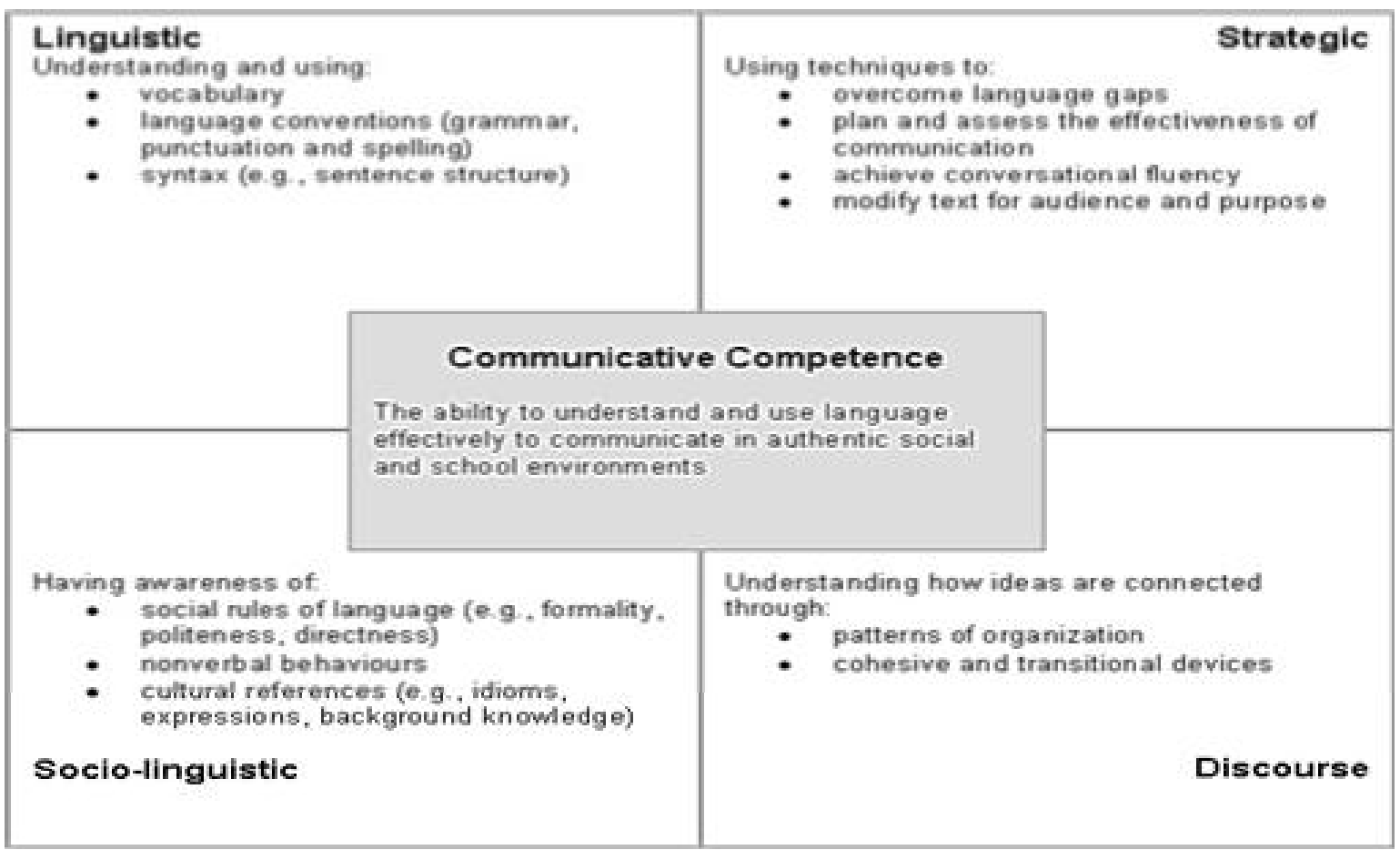

Fig. 1. Structure of communicative competence [7].

The broad aim of language education is to communicate independently in a foreign language. This is based on the premise that language skills learned in classrooms are easily transferable to real-life situations, and $\mathrm{PhD}$ students are to become proficient at the end of a language programme. But this isn't the case and results almost always fall short of this expectation. Analysis of the national programmes on English for preparing $\mathrm{PhD}$ students allows to conclude that language communicative competencies in an academic environment include:

- identifying the purpose, structure, style and following the content requirements for writing and speaking in academic environment;

- development of communication skills in academic English field;

- expression of ideas with clarity and precision in their field of research;

- use of formal style and selecting of relevant verbal strategies depending on the genre and purpose of academic expression;

- demonstration of natural and smooth flow of language;

- argueing a research position convincingly in oral academic communication;

- structuring of written texts and oral messages appropriately;

- planning and implementation of the writing process, organizing the structural parts of a text (introductory, body, and concluding parts);

- constructing a thesis statement, main points and supporting ideas and details;
- applying of a variety of writing patterns (defining, classifying, contrast/comparison, cause/effect, argumentative);

- use of varied sentence structure;

- paraphrasing and summarizing academic texts;

- ensuring coherence of the written text, including the use of efficient transitions;

- ackquired knowledge on how to avoid plagiarism (intentional and unintentional) in writing;

- awareness of requirements for references in academic writing and presentations;

- ackquired knowledge on how to use quotations and in-text citations in academic writing;

- planning, outlining, and delivery of an oral academic presentation;

Among them there can be stated such writing competencies as: - understanding the nature, structure, and stylistic features of an abstract for an academic article, conference abstract; - mastering the grammar features, including use of tenses, voice, sentence structure of an abstract for an academic article, conference abstract; - mastering the vocabulary and stylistic features of writing an informative and well balanced abstract for an academic publication; - knowledge on the typical procedure stages of submitting a conference proposal [3].

The importance of English for access and empowerment is recognized in Ukraine and reflected in a number of national strategies and initiatives where the English language proficiency is central, including: recognition of the need to ensure the competitiveness 
of Ukrainian scholars and graduates nationally and internationally; desire to internationalize higher education; programmes for academic and educational integration within the EU, etc. [3].

Nowadays a lot of scientists $[4 ; 6]$ underestimate the difficulty involved in studying a foreign language communication. This is because foreign language acquisition goes beyond comprehension. It also involves socialisation and emotion.

The high level of personal engagement is required and it is even more challenging at universities, where $\mathrm{PhD}$ students struggle to meet the demands of an academic life [1].

A growing body of articles [2;5] underscores the importance of a shift in thinking and getting necessary competence in the field of language communication. It's clear that a purely cognitive approach to learning, even if learner-centered and communicative, won't guarantee student engagement. More emphasis on the experience of learning a language is required in teaching.

This means that more attention should be paid to a learner subjectivity and experience - an important component of language acquisition [6].

There is some misunderstanding between teaching and studying in this difficult process to get necessary language competence. A person who has studied English - or any other foreign language for that matter - very often feels apologetic, inadequate or even guilty for their language skills. People often put their difficulties in getting communicating competence down to not being «good at languages». But in reality, there are a number of factors that hinder acquisition. These have little to do with students' aptitudes, limitations and levels of motivation in getting language competence [4].

Studying a foreign language in an institutional context comes with structural constraints. These include limited contact time and a lack of socialisation into the language through an existing community that speaks the target language. One way to counter these obstacles is involving communicative situations in classrooms such as structured dialogues, pair and group work, discussions and interviews. But these approaches are often too artificial and ritualised - teachers and learners are trapped in their respective roles and the spontaneity that characterises real-life communication situations remains elusive. Often, language knowledge doesn't always transfer to knowledge от how to use language in the communication process.

The idea of the gaining language communicative competence like a «native speaker» as a model of proficiency still defines language education, even though it is unrealistic and impossible to define. Language errors are often stigmatised instead of being viewed as a natural and meaningful part of building communicative skills. Teachers, who banish the students' first language from the classroom, disempower learners, who are already vulnerable in expressing themselves in the language they're studying as they cann't develop their communicative competences in another language properly. All of the factors mentioned above contribute to a negative learning experience, poor communicative abilities and linguistic insecurity, which in turn leads to low results.

Changing student's culture is another important factor, which can cause difficulties in the process of acquiring the language competence [8]. These difficulties are compounded by the fact that $\mathrm{PhD}$ students face significant challenges. Financial pressures due to structural inequalities, academic unpreparedness and increasingly, mental health disorders have become a common feature of university life. On the whole, $\mathrm{PhD}$ students seem to lack the learning strategies and emotional resilience required to successfully complete academic courses. As a result the student's culture changes very rapidly. The democratization of learning environment has come under the spotlight again and is intensified by the student-driven movement of independence. Students lay a claim to their own histories and identities which have been historically marginalized. As a result, learner subjectivity and experience are afforded more importance in teaching and learning settings at universities. This affective (emotional) dimension of language acquisition is often overlooked in teaching.

Nowadays the value of studying is increased very much. In light of this, educators and $\mathrm{PhD}$ students are to spend much time talking on why and how they teach and learn languages. This would go far in addressing the immediate needs of students. It would also broaden the scope of teaching beyond its typically results-based, utilitarian focus [7].

Addressing studying in itself would firstly develop learning strategies and cultivate self-awareness in students who are emotionally and academically illequipped to study independently. It would link the learning process to self-development, which goes beyond linguistic knowledge and know-how.

Conclusion. Today the aim of post-graduate education is not only the growth of usage of lexical and grammar materials in the training of a competent specialist. In theory, post-graduate education established the imperative of the competencebased approach, while at practice communicative competencies aren't directed to the process of inclusion of $\mathrm{PhD}$ students in the professional culture and remain underestimated. The prospects for further scientific research could be presented in the study and analysis of training and competencies development of PhD students.

\section{Список використаної літератури}

1. Вступні іспити до аспірантури. Постанова кабінету Міністрів України № 261 від 23 березня 2016 року «про затвердження порядку підготовки здобувачів вищої освіти ступеня доктора філософії та доктора наук у вищих навчальних закладах (наукових установах)». URL: http://langcenter.kiev.ua/navch_vstup.html (дата звернення 12.09.2020)

2. Духаніна H.M. Особливості навчання іноземних мов здобувачів вищої освіти ступеня доктора філософії (PhD). Young Scientist. 2018. № 4 (56) C.489-492. URL: https://www.google.com/search?q-1C1OKWM_ruUA913UA913\&o.

3. Концептуальні засади державної політики щодо розвитку англійської мови у сфері вищої освіти. URL: https://mon.gov. ua/storage/app/media/2019-06-24-proekt-konts-angl-movi-1.docx (дата звернення 12.09.2020)

4. Обучение иностранному языку в аспирантуре неязыкового вуза: актуальные вопросы: монография / Г.В.Буянова, и др. Пермь: ИПЦ «ПРОКРОСТЪ», 2017.188 с.

5. Пелех Л.Р. Забезпечення якості самостійної роботи аспірантів з вивчення іноземної мови на основі впровадження засадничих психолого-педагогічних принципів. Зб. наук. пр. Східноукр. нац. ун-т ім. В.Даля. 2015. вип. 1(64). С.180-199.

6. Петрова О.Б., Попова Н.О. Аспект наукової підготовки при вивченні іноземної мови у немовному ВНЗ. Проблеми та перспективи розвитку науки на початку третього тисячоліття у краӥнах Свропи та Азї̈: зб. наук. пр. матеріалів XV міжнар. наук.-пр. інтер-конф. (Переяслав-Хмельницький, 30 червня - 1 липня 2015 р.). Переяслав-Хмельницький: Переяслав-Хмельницький державний педагогічний університет ім.Григорія Сковороди, 2015. С.205-207.

7. Ярославова Е.Н., Федотова М.Г. Особенности организации обучения иностранному языку аспирантов неязыкового вуза. Наука ЮУрГУ: материаль 67-й научной конференции Секции сойиально-гуманитарных наук (Челябинск, 14-17 
апреля 2015 г.). Челябинск: Южно-Уральский государственный университет , 2015. С.1208-1215.

8. Structuring cooperation in doctoral research, transferrable skills training, and academic writing instruction in Ukraine's regions. Academic Writing. CURRICULUM. Courses description. Developed by P4 Simon Kuznets Kharkiv National University of Economy. URL: https://www.hneu.edu.ua/erasmus-dochub. (дата звернення 12.09.2020)

\section{References}

1. Vstupni ispyty do aspirantury. Postanova kabinetu Ministriv Ukrainy № 261 vid 23 bereznia 2016 roku «Pro zatverdzhennia poriadku pidhotovky zdobuvachiv vyshchoi osvity stupenia doktora filosofii ta doktora nauk u vyshchykh navchalnykh zakladakh (naukovykh ustanovakh)» [Entrance exams for PhD. Resolution of the Cabinet of Ministers of Ukraine № 261 of March 23, 2016 «On approval of the procedure for training applicants for higher education for the degree of Doctor of Philosophy and Doctor of Science in higher educational institutions (scientific institutions)»] (2016). http://langcenter.kiev.ua/ navch_vstup.html [in Ukrainian].

2. Dukhanina, N.M. (2018). Osoblyvosti navchannia inozemnykh mov zdobuvachiv vyshchoi osvity stupenia doktora filosofii $(\mathrm{PhD})$ [Features of teaching foreign languages to graduates of the degree of Doctor of Philosophy (PhD)]. Young Scientist, 4 (56), 489-492.

3. Kontseptual'ni zasady derzhavnoyi polityky shchodo rozvytku anhliys'koyi movy u sferi vyshchoyi osvity. Proyekt [Conceptual principles of state policy on the development of the English language in the field of higher education]. https://mon.gov.ua/ storage/app/media/2019-06-24-proekt-konts-angl-movi-1.docx

4. Buianova, H.V., Kynderknekht, A.S., Popova, T.V., \& Peunova, E.V. (2017). Obuchenye ynostrannomu yazyku v aspyranture neiazykovoho vuza: aktualnye voprosy [Teaching a foreign language in graduate school of a non-language university: current issues]. PROKROST». [in Russian].

5. Pelekh, L.R. (2015). Zabezpechennia yakosti samostiinoi roboty aspirantiv z vyvchennia inozemnoi movy na osnovi vprovadzhennia zasadnychykh psykholoho-pedahohichnykh pryntsypiv [Ensuring the quality of independent work of graduate students in learning a foreign language on the basis of introduction of basic psychological and pedagogical principles. Collection of Scientific Works of East-Ukrainian V.Dal Univercity, 1 (64), 180-199. [in Ukrainian].

6. Petrova, O.B., \& Popova, N.O. (2015, July 1). Aspekt naukovoi pidhotovky pry vyvchenni inozemnoi movy u nemovnomu vnz [Aspect of scientific training in the study of a foreign language in a non-language university). Proceeding of XV International scientific-practical internet conference-Problems and prospects for the development of science at the beginning of the third millennium in Europe and Asia) (pp.205-207). H.Skovoroda Pereyaslav-Khmelnytsky State Pedagogical University. [in Ukrainian].

7. Iaroslavova, Ye.N., \& Fedotova, M.H. (2015). Osobennosty orhanyzatsyy obuchenyia ynostrannomu yazyku aspyrantov neiazыkovoho vuza [Features of the organization of foreign language training for graduate students of a non-language university. Proceeding of $67^{\text {th }}$ sciemntific conference on Social-humanitarian sciences (pp.1208-1215). South Ural State University. [in russian].

8. Structuring cooperation in doctoral research, transferrable skills training, and academic writing instruction in Ukraine's regions. Academic Writing. CURRICULUM. Courses description. https://www.hneu.edu.ua/erasmus-dochub.

Стаття надійшла до редакції 14.10 .2020 р. Стаття прийнята до друку 20.10.2020 р.

Гарапко Віталія Іванівна

кандидат педагогічних наук, доцент

кафедра англійської філології та методики викладання іноземних мов

Мукачівський державний університет

м. Мукачево, Україна

\section{РОЗВИТОК АНГЛОМОВНОЇ КОМПЕТЕНТНОСТІ В СТУДЕНТІВ-АСПІРАНТІВ В УМОВАХ АКАДЕМІЧНОГО СЕРЕДОВИЩА}

Анотація. Високий рівень особистого залучення, якого вимагає процес вивчення іноземної мови, є ще більш складним для наших університетів, де вимоги академічного середовища настільки високі, що не всі аспіранти здобувають необхідних компетентностей задля задоволення цих вимог. Метою статті є дослідити передумови набуття іноземної мовної компетенції в академічному середовищі та отримати необхідну інформацію, необхідну для подальших досліджень. Методологія дослідження будується здебільшого на теоретичних методах, таких як: аналіз наукових робіт та публікацій. Сучасний стан освітніх послуг вказує на значне підвищення потреби у високоякісній професійно-спрямованій освіті, яка забезпечуватиме здобувача відповідними компетнціями актуальними для академічного середовища. У світлі цього викладачам та аспірантам слід витрачати набагато більше часу на розмови про те, чому і як вони викладають та вивчають мови. Сьогодні метою післядипломної освіти є не лише збільшення використання лексичних та граматичних матеріалів у підготовці компетентного фахівця. Теоретично післядипломна освіта встановила імператив підходу, заснованого на компетентностях, тоді як практично комунікативні компетенції не спрямовані на процес включення аспірантів у професійну культуру, занижуються і в неповній мірі реалізуються ними в академічному освітньому середовищі.

Ключові слова: комунікативна компетентність; компетентність з іноземних мов; аспіранти; труднощі в процесі набуття мовної компетенції; академічне середовище. 